\title{
Legal Basis for Licensing and Permitting Activities of Internal Affair Bodies in the Kyrgyz Republic (Soviet and Present Period)
}

\author{
Marat Tatenov' ${ }^{1}$, Nurbek Tabaldiev', Ermek Nurbaev ${ }^{1}$, Aidana Zhumabayeva1, \\ Zhazgulim Toktorova1, Gulaiym Abrakhmanova', Gulsara Kuldysheva1, \\ Zhypargul Abdullaeva ${ }^{2 *}$ (1)
}

${ }^{1}$ Department of Theory and History of Government Law, Osh State University, Osh, Kyrgyzstan

${ }^{2}$ Science and Research Department, Osh State University, Osh, Kyrgyzstan

Email: *jypar.science@oshsu.kg

How to cite this paper: Tatenov, M., Tabaldiev, N., Nurbaev, E., Zhumabayeva, A., Toktorova, Z., Abrakhmanova, G., Kuldysheva, G., \& Abdullaeva, Z. (2022). Legal Basis for Licensing and Permitting Activities of Internal Affair Bodies in the Kyrgyz Republic (Soviet and Present Period). Open Journal of Social Sciences, 10, 478-486. https://doi.org/10.4236/jss.2022.101035

Received: December 14, 2021

Accepted: January 25, 2022

Published: January 28, 2022

Copyright $\odot 2022$ by author(s) and Scientific Research Publishing Inc. This work is licensed under the Creative Commons Attribution International License (CC BY 4.0).

http://creativecommons.org/licenses/by/4.0/

\begin{abstract}
Creative comprehension of experience and its practical application is a source of further growth and improvement. In this regard, the historical study of Kyrgyzstan's internal affairs members acquires great cognitive and educational values. The licensing and permitting system institution origin and its development inextricably linked with the Soviet power supremacy period. The legal basis for Soviet militia organization was the RSFSR decree of People's Commissariat of Internal Affairs "On the Workers' Militia" of November 10, 1917. Historical, comparative analysis and descriptive research methods were performed in this article to establish understandings of a legal basis for licensing and permitting activities of Kyrgyz Republic Internal Affair members. The research aim in this work was to analyze legal basis for licensing and permitting activities of internal affair bodies in the Kyrgyz Republic including the Soviet and present period. Research methods such as historical-comparative and descriptive analysis were used.
\end{abstract}

\section{Keywords}

Legal Basis, Licensing and Permitting Activities, Internal Affair Bodies, Kyrgyz Republic, Soviet and Present Period

\section{Introduction}

At the end of 1917 and beginning of 1918, in all cities of Central Asia and Kazakhstan local Soviets, guided by decree of RSFSR "On the workers' militia" and "Regulations on the Red Guard" developed by Tashkent Council Deputies and 
approved by the central election committee, militia detachments and self-defense squads were formed to protect against mass banditry and Basmachism (Strelnikov, 2015). Published by the Council of People's Commissars of RSFSR on December 10, 1918 (Decree on Council of People's Commissars of the RSFSR, 1918), the "Decree on surrender of weapons" (History Museum of Russian Reforms, 2021) became the legal basis for activities of police to implement the licensing system. The decree on surrender of weapons in a harsh form obliged to surrender firearms and edged weapons owned by the civil population; those guilty who was convicted of attempting to conceal weapons or resisting their surrender were punishable by imprisonment for a term from 1 to 10 years.

With the adoption of decree, all previously issued permits for storage and carrying of weapons lost their legal force. The only exceptions were party members, whose weapons were not confiscated by the Russian Communist Party recommendation if there were no more than one rifle and one revolver per person.

On July 28, 1920, the Decree by Council of People's Commissars of the RSFSR "On Hunting" was adopted, which limited the circle of persons who were granted the right to own hunting weapons. According to this act, only citizens with a hunting ticket could now use a hunting weapon (Decree on People's Commissars Councils of RSFSR, 1920b).

Central Executive Committee regulation and the Council of People's Commissars of the USSR from March 29, 1935 "On measures to combat hooliganism" was a normative and legal document securing the permissive powers of internal affairs bodies concerning cold steel (Decree on People's Commissars Councils of RSFSR, 1920c). According to above decree, without relevant permits, activities related to the manufacture, storage, sale, and wearing of daggers, sabers, Finnish knives and similar edged weapons were declared illegal and were prohibited. This document also provided administrative control by the Peoples Commissariat of Internal Affairs over the strict observance of rules for the manufacture and sale of knives.

The involvement of police for further development of licensing system undoubtedly played an important role, in this regard, on July 12, 1920, the Council of People's Commissars adopted a decree "On the issue and storage of firearms and their handling” (Decree on People's Commissars Councils of RSFSR, 1920a).

Following this document, militia together with the All Russian Extraordinary Commission was directly charged with monitoring the implementation of rules for weapons issue and storage. The decree adopted by the Council of People's Commissars "On the Issuance and Storage of Firearms and the Handling", along with administrative responsibility, secured judicial liability for illegal possession of firearms, where punishment was authorized for a period of at least 6 months (Decree on People's Commissars Councils of RSFSR, 1920a), while administrative responsibility provided for punishment in the form of imprisonment in a concentration camp for up to 3 months (Anisimov, 2003).

According to the Council of People's Commissars of the RSFSR decree from 
July 9, 1924 (Questions of Soviet Government and Law, 1968), weapon types and ammunition were listed in detail. The weapon trade was carried out with permission of police and the United State Political Administration (USPA). In the same year for the first time, by a resolution of the All-Russian Central Executive Committee, to establish a uniform order throughout the USSR, all weapons, ammunition and explosives located within the country were divided into three categories: "A", "B" and "C" (Kostyleva, 2005).

On December 12, 1924, the All Russian Central Executive Committee of the USSR adopted a resolution "On the procedure for the production, trade, storage, use, accounting and transportation of weapons, firearms, explosive shells and explosives" (Decree on People's Commissars Councils of RSFSR, 1924). Consequently, a special regime was established for the handling of explosive materials (Miehe et al., 2015). The resolution of the All-Russian Central Executive Committee and the Council of People's Commissars and the resolution of the Council of People's Commissars of RSFSR on October 8, 1927, adopted on September 3 , 1927, played a significant role in further development of licensing system. According to these regulations, the powers of structural units of the administrative and legal departments and the relevant members in the USPA to control the circulation of weapons are distributed in detail (Soviet militia, 1957).

By the beginning of 1930, the development of licensing system found its logical continuation given the expansion and concretization of police functions in the field of administrative supervision. According to the resolution adopted on May 26, 1930, by the Council of People's Commissars of the RSFSR (The USSR Council of People's Commissars Resolution, 1935), permission for acquisition, storage and use of rifled hunting weapons were issued for three years.

In the period from the 30 s to 40 s, a distinct tendency formed in the licensing system's main sphere of weapons trafficking. It is also important to note that militia activity as well as other government bodies regulated by various sub-laws and departmental acts. Resolution of various conflict situations between participants in public relations based on the norms of law, which is carried out by specially authorized government power bodies (Batyrbaev et al., 2021).

In this work, the overall research problem and objectives are focused on various decrees issued by the government to control legal activities on weapons used by internal affairs bodies in the Kyrgyz Republic.

\section{Research Methods and Materials}

Research results in this article were obtained from historical-comparative, formal-logical, general and historical law methods and previously published literature analysis based on obtaining new knowledge by comparing historical and legal sources (Shigal, 2013). Research design was build on the historical-comparative analysis of legal basis for licensing and permitting activities by internal affair bodies in the Kyrgyz Republic including Soviet and present period. 


\section{Results and Discussions}

\subsection{Legal Regulation Activities}

In general, legal regulation of activities of the internal affairs bodies of Soviet Kyrgyzstan did not differ from other republics that were part of the USSR. Until 1936, as part of the RSFSR, Kyrgyzstan existed as an autonomous republic, accordingly, all decisions and decrees issued by the government of the RSFSR were binding, including on the territory of Kyrgyzstan.

In the period from 1941-1945 during the Great Patriotic War, the licensing activity of the internal affairs bodies was regulated by Decree of Supreme Soviet Presidium of the USSR on June 22, 1941.

Further transformation of a regulatory legal framework for activities of internal affairs bodies in the licensing system field in post-war period was associated with adoption of Fundamentals of Criminal Legislation in the USSR and the Union Republics in 1958, as well as the entry into force on October 27, 1960, of the Criminal Code of the RSFSR (The USSR Council of People's Commissars Resolution, 1935).

In November 1968 following the Decree of Supreme Soviet Presidium of the USSR, the Ministry of Public Order was renamed into the Ministry of Internal Affairs of the USSR. In 1969, the structure of the Ministry of Internal Affairs of the Kyrgyz SSR underwent dramatic changes, due to which, several independent structural divisions of the departments were created, including the department for the protection of public order.

On September 22, 1971, by order of the USSR Ministry of Internal Affairs, the organizational and inspection directorates of the Union republics were transformed into headquarters.

With adoption of Resolution by Council of Ministers of the USSR on July 23, 1975, "On the establishment of a unified procedure for the acquisition, accounting and storage of hunting rifles" (RSFSR Criminal Code, 1960), as well as the Decree of the Presidium of the Supreme Soviet of the Kyrgyz SSR. On liability for violation of rules for the acquisition, registration, use and storage of firearms weapons, the role of the licensing system in the maintenance of public order and the fight against crime has tremendously increased.

During the period from 1976 to $1980^{\text {th }}$ in the framework of increasing the effective fight against crime related to the use of firearms and explosives, the criminal liability for the illegal carrying, possession, acquisition, manufacture, or sale of firearms, ammunition, or explosives has been increased.

By order of the USSR Ministry of Internal Affairs dated May 6, 1987, an instruction was approved on the internal affairs bodies' work to implement the licensing system. In this act, for the first time, the most voluminous and specific tasks by internal affairs bodies were set out to prevent violations of rules for acquisition, accounting, storage, transportation and use of items and substances for which a special regime of use has been established.

The following order by the Ministry of Internal Affairs of the USSR No. 246 
on December 1, 1987, approved an instruction regulating the procedure for acquisition, transportation, storage, accounting and use of firearms, as well as their ammunition, manufacture of cold bladed weapons; the opening of shooting ranges, shooting ranges, shooting and hunting stands, weapons repair shops; trade in firearms, ammunition and hunting knives.

We believe that these two important documents, approved in 1987, became for many post-Soviet governments as a kind of legal basis for preparation and adoption of laws "On weapons". In Kyrgyzstan, throughout the post-Soviet period, the number of crimes related to use of weapons, explosives, as well as implementation of private detective and security activities has significantly increased.

Development of licensing and permitting systems in the period from 1991 to 1992s was due to the necessity in introduction of new economic reforms. The government in these conditions was interested in an intensification of private entrepreneurship, but its implementation outside the government regulation was not possible. There is a need to introduce legal methods for effective measurement protection of citizens' rights, as well as licensing economic security in Kyrgyzstan.

National models of weapons trafficking in different countries differ in many ways, for example by degree of monopolization of weapon manufacturers, the centralization or decentralization of weapons legal regulation in their circulation (Zyryanov, 2017). Problems of legal regulation, turnover of civil weapons service were examined in detail, and their legal features were studied based on the existing legislations and scientific theory on weapons definition (Stepovoy, 2012).

\subsection{Legislative Framework Modernization by Constitutional Adoptions}

With the Kyrgyz Republic Constitution adoption in 1993, it became necessary to modernize the legislative framework for organization and activities of law enforcement agencies (Sartaeva, 2011; Keping, 2018; Derencinovic \& Getos, 2007). The problem of civilian self-defense weapons is viewed today not only from the administrative law point of view but also from the constitutional, criminal laws, criminalistics and criminology views (Koshelev, 2011).

In this regard, on January 11, 1994, the Law of the Kyrgyz Republic "On the Internal Affairs Bodies of the Kyrgyz Republic" No. 1360 was adopted. Under the Law of the Kyrgyz Republic "On the Internal Affairs Bodies of the Kyrgyz Republic", the structure of the internal affairs bodies includes the Public Security Department of the Ministry of Internal Affairs of the Kyrgyz Republic, as well as the Internal Affairs Directorate of the regions and Bishkek, city district bodies of internal affairs that carry out-licensing activities (Kyrgyz Republic Law, 1994).

To regulate legal relations arising from the circulation of civil, service, as well as combat hand, held small arms and cold weapons in the Kyrgyz Republic territory and to ensure the protection of citizens life and health, property, ensuring public and economic security, protecting nature and natural resources, and de- 
veloping international cooperation in the fight against crime and illegal proliferation of weapons, on June 9, 1999, the Law of the Kyrgyz Republic "On Weapons" No. 49 was adopted (Kyrgyz Republic Law, 1999). The provisions of this Law also apply to the circulation of ammunition for weapons.

To determine control over the circulation of firearms, on November 21, 2001, by the Resolution of Kyrgyz Republic Government No. 721, the "Rules for circulation of civilian and service weapons and their ammunition in the Kyrgyz Republic" were approved. Following these rules, a procedure has been established for circulation of service and civilian weapons and their ammunition, providing for their sale, transfer, acquisition, accounting, storage, carrying, transportation, use, withdrawal and destruction, export and import, as well as an import into the territory of Kyrgyz Republic and export from the Kyrgyz Republic of weapons individual copies ammunition were established (Kyrgyz Republic Government Resolution, 2001).

By the Kyrgyz Republic Internal Affairs Ministry order No. 144 of April 2, 2002, the Instruction on Internal Affairs Directorate work to control the circulation of service and civilian weapons and the procedure for opening shooting ranges, shooting and hunting stands, weapon repair shops were approved. By order of the same day No. 145, instruction on permitting system implementation work was approved. For almost 9 years, these acts have regulated the licensing activities of Internal Affairs Directorate in the Kyrgyz Republic.

\subsection{Kyrgyz Republic Laws and Resolutions}

The most important government legal acts regulating many conceptual issues of reforming the internal affairs bodies in 1998 and 2005 were the Decree of the Government of the Kyrgyz Republic No. 490 of 23.07.1998, as well as the Decree of the President of the Kyrgyz Republic No. 76 of 18.03.2005 "On Approval of the Concept reforming the internal affairs bodies of the Kyrgyz Republic until 2010". Based on these acts, the Concept of Reforming the Internal Affairs Directorate of Kyrgyz Republic was adopted. It was decided to carry out large-scale transformations aimed at cardinal changes in the system and structure of the Ministry of Internal Affairs of the Kyrgyz Republic, this decision was partially implemented.

Approved by the Kyrgyz Republic Ministry of Internal Affairs order No. 513 from June 9, 2009 the Main Directorate Public Security regulation of Kyrgyz Republic Internal Affairs Ministry was aimed at further development of police department activities in the field of licensing and permitting work and control over detective and private security activities (Kyrgyz Republic Internal Affairs, 2009).

Following the Kyrgyz Republic Law "On Regulatory Legal Acts of the Kyrgyz Republic" and Resolution by the Kyrgyz Republic Government from February 15, 2011 No. 47, the "Instruction on the work of internal affairs bodies for implementation of control and licensing functions" and "Instruction on the work 
of the internal affairs bodies on control over the circulation of service and civilian weapons, ammunition for them and on the procedure for opening weapons repair shops." Based on this Resolution of Government, the previously issued orders by the Kyrgyz Republic Ministry of Internal Affairs on April 2, 2002 No. 145 , the turnover of service and civilian weapons and the procedure for opening shooting ranges, shooting and hunting stands, weapons repair shops.

Above-mentioned Kyrgyz Republic law from June 9, 1999 No. 49 "On weapons" currently regulates the circulation of weapons in government (Kyrgyz Republic Internal Affairs, 2009). Following this normative legal act, the production, repair and trade of weapons and ammunition in the Kyrgyz Republic territory are subject to licensing, the only exception is the production and purchase of weapons by government paramilitary organizations. All models of civilian and service weapons and cartridges produced on the Kyrgyz Republic territory were imported into republic territory and exported from the republic, as well as products structurally similar to weapons, are subject to mandatory certification.

The Kyrgyz Republic internal affairs bodies authorized to issue a license for weapons sale, collecting, exhibition and licenses for their production. The internal affairs bodies also issue permits to legal entities and citizens for the acquisition, storage and carrying of civilian and service weapons and cartridges (Kyrgyz Republic Internal Affairs, 2009).

Research findings are various decrees and laws issued by the Kyrgyz Republic government to regulate and manage activities on weapons use as well as products structurally similar to weapons subject to mandatory certification.

\section{Conclusion}

In summary, it should be noted that with the progressive development of our government; the tasks and functions of internal affairs bodies also become more complicated. To minimize, as well as regulate the procedure for using controlled objects, the country has adopted some legislative documents that determine the functions and focus of executive authorities in the field of their direct activities. Research implications in this work were determined as rules; procedures have been established by government bodies for civilian weapons use and their provisions for sale, transfer, acquisition, accounting and storage.

\section{Conflicts of Interest}

The authors declare no conflicts of interest regarding the publication of this paper.

\section{References}

Anisimov, N. N. (2003). Problems of Improving the Licensing and Permitting Activities of Internal Affairs Bodies. Thesis, Russian Federation Ministry of Internal Affairs, Moscow Academy, $148 \mathrm{p}$.

Batyrbaev, B., Aidarbekova, G., Toktombaeva, A., Salybekova, T., Ganieva, T., Gulsara, K., \& Abdullaeva, Z. (2021). Legal Policy and Legal Culture in the System for Public 
Administration and Judiciary in the Kyrgyz Republic. Open Journal of Social Sciences, 9, 53-61. https://doi.org/10.4236/jss.2021.97005

Decree on Council of People's Commissars of the RSFSR (1918). On the Surrender of Weapons.

Decree on People's Commissars Councils of RSFSR (1920a). On the Issuance and Storage of Firearms and Handling.

Decree on People's Commissars Councils of RSFSR (1920b). On Hunting.

Decree on People's Commissars Councils of RSFSR (1920c). On Measures to Combat Hooliganism.

Decree on People's Commissars Councils of RSFSR (1924). https://articlekz.com/article/10236

Derencinovic, D., \& Getos, A. (2007). Cooperation of Law Enforcement and Intelligence Agencies in Prevention and Suppression of Terrorism: European Perspective. Revue internationale de droit pénal, 78, 79-112. https://doi.org/10.3917/ridp.781.0079

History Museum of Russian Reforms (2021). Laws about Weapon 1918-1920. http://museumreforms.ru/node/13766

Keping, Y. (2018). Governance and Good Governance: A New Framework for Political Analysis. Fudan Journal of the Humanities and Social Sciences, 11, 1-8. https://doi.org/10.1007/s40647-017-0197-4

Koshelev, A. M. (2011). Civilian Self-Defense Weapons as a Subject of Administrative and Legal Regulation. Bulletin of the Moscow University of the Ministry of Internal Affairs of Russia, 5, 158-161.

Kostyleva, K. I. (2005). Administrative and Legal Regulation of Licensing and Permitting Activities. Thesis, Moscow State Juridical Academy, 172 p.

Kyrgyz Republic Government Resolution (2001). On Approval of the Rules for the Circulation of Civilian and Service Weapons and Ammunition in the Kyrgyz Republic. November 21, No. 721 .

Kyrgyz Republic Internal Affairs (2009). Order of Ministry No. 513 on Approval of Regulations on the Public Security Main Directorate the Ministry of Internal Affairs of Kyrgyz Republic, 9 June.

Kyrgyz Republic Law (1994). On the Internal Affairs Bodies of the Kyrgyz Republic. Dated January 11, No. 1360-XII.

Kyrgyz Republic Law (1999). On Weapons. June 9, No. 49.

Miehe, R., Mueller, S., Schneider, R., Wahren, S., \& Hornberger, M. (2015). Integrated Hazardous Materials Management: Combining Requirements from Various Environmental Legislations to Enable Effective Business Compliance Processes in Industries. International Journal of Precision Engineering and Manufacturing-Green Technology, 2, 289-298. https://doi.org/10.1007/s40684-015-0035-6

Questions of Soviet Government and Law (1968). Materials of the Scientific Conference of the North Caucasus Region. Rn-D., S.U. 1917-1918. No. 93. Art. 993, 66.

RSFSR Criminal Code (1960). http://www.consultant.ru/document/cons_doc_LAW_2950/

Sartaeva, N. A. (2011). Legislative Foundations for the Activities of Law Enforcement Agencies and Their Improvement. Bulletin of the Institute of Legislation and Legal Information of the Republic of Kazakhstan, 4, 130-138.

Shigal, D. A. (2013). The Theory of the Historical and Legal Comparative Method. Legality Problems, 124, 1-8. 
Soviet Militia (1957). Collection of Legislative Documents on the Organization and Activities (pp. 98-99). Higher School of the USSR Ministry of Internal Affairs. Moscow, No. 225.

Stepovoy, R. A. (2012). On the Question of the Concept and Legal Features of Civilian and Service Weapons. Problems of Economics and Legal Practice, No. 2, 172-175.

Strelnikov, D. P. (2015). Kyrgyz Republic Police History. Questions in the History of Kyrgyzstan, 1-2, 59-69.

The USSR Council of People's Commissars Resolution (1935, July 21). On the Manufacture of Seals and Stamps and Their Use.

Zyryanov, S. M. (2017). Administrative and Legal Models of Civilian Arms Turnover in the Russian Federation and in Foreign Countries. Journal of Foreign Law and Comparative Law, 1, 62-67. 